\title{
The Application Exploration of Lexical Chunks Teaching Method in College English Writing Driven by Language Consciousness
}

\author{
Zhang Wei \\ Jilin Business and Technology College \\ 182076127@qq.com
}

\begin{abstract}
Language chunk is a special kind of multi-word lexical structure with certain grammatical meaning and pragmatic function and is relatively fixed in the form. Lexical chunk teaching method is an effective way of college English teaching reform. This study makes a combination of language consciousness theory and traditional language chunk teaching method, trying to draw up a new mode of teaching driven by language consciousness and conducting research in teaching practice. On the basis of analyzing language chunk teaching method and language consciousness theory, this paper points out that lexical chunk teaching method based on the theory of language awareness is more advantageous to helping students overcome the negative transfer of native language barriers, promoting the accuracy of the language expression, enhancing the vitality of the language expression and improving the fluency of language output.
\end{abstract}

Keywords-language consciousness; teaching method of lexical chunks; college English writing

In terms of the difficulty of college English teaching and an important output of language skills in a written form, college English writing can most reflect the students' English level and their ability of using language. However, the college English writing teaching effect of China's most universities and colleges is not ideal, and students' English writing ability is poor after years of English learning. There are a considerable number of phenomena in the composition writing, such as improper use of words, literal translation of words, incorrect collocations, wrongful sentences and impassable statement.

From the teaching practice in recent years, the author finds that students get lower scores in CET exams, in especially writing. So, how to improve college English writing teaching method and students' writing skills step by step is one of the problems that college teacher face and need to solve. In recent years, corpus linguistics and second language learning theory are being gradually introduced into college English writing teaching class and the application effect of lexical chunk theory is a major concern in second language teaching and learning. The author in teaching practice also has carried on the deep empirical research on the application of this theory and confirms that the proper use of lexical chunks theory to guide the teaching of college English writing can effectively improve the teaching effect.

\section{OVERVIEW OF RELATED THEORIES}

\section{A. Language consciousness theory}

From the angle of language education, Carter believed that language consciousness is a kind of consciousness and sensitivity of the learners in terms of language function and form, designed to encourage students to think about language and pay attention to language carrier, language change and language difference (Carter, 2003:1-3). Yang Min believed that language consciousness is the operation mechanism referring to mental activities and is a psychological cognitive process different from language sense (Yang 2008:74-74).

The author thinks that the language sense is a kind of abstract and complicated psychological process in which learners will internalize and generate the specific language knowledge. Language sense is mainly divided into two aspects, one is the structure consciousness of language, and the other is the application awareness of language. Structure consciousness determines people to understand and apply grammar, and application refers to how to apply language in the actual use of the target culture. Therefore, how to effectively stimulate the learners' consciousness of the language structure and application is very important to improve their ability of language output on the whole. Unfortunately, there are few existing researches on language consciousness theory applied to college English teaching in domestic academic fields in the current years. Therefore, this paper driven by the theory of language consciousness aims to reinterpret the connotation of language chunks teaching method and put forward the new mode in college English writing teaching[1].

\section{B. Language chunks teaching method}

Linguists represented by Michael Lewis put forward the concept of lexical chunks, thinking language is not composed of vocabulary and grammar that the conventional wisdom suggests, but mainly consists of lexical chunks. It fuses the "form" and "function" of language and reflects the relationship between the semantics, syntaxes and pragmatics, which can promote the development of the rules of grammar, help to improve the accuracy of language expression and reduce the burden of language processing and output. Studies have shown that the essential difference between native speakers and 
foreign language learners lies in that the former usually is able to grasp tens of thousands of prefabricated language chunks, thus ensuring its language expression to be pure and smooth; The latter need makes a temporary combination of sentences according to the rules of grammar, the words used are far from the standard requirements of native English, so there is a certain gap in the fluency of language expression between native speakers and foreign language learners. The teaching mode of lexical chunks put forward by Lewis pays particular attention to the learners' identification and learning of lexical chunks, so learners can involve themselves into the activities of various forms organized by the teachers. The function and character of lexical chunks determine it to be an integrated and comprehensive teaching process. Learners not only need to learn words and idioms, but also must learn the syntax structure and pragmatic functions of language. A number of studies have found that using the habitual language chunks will overcome the impact of traditional grammar translation in language teaching, improve the fluency and accuracy of language and thus overcome the impact of negative transfer of mother tongue. At present, the most commonly used mode of lexical chunks in the classroom is: observation of lexical phrases in the written language, understanding of language chunks in the form and function, memorization of lexical chunks and practical use of the language chunks in the composition[2]. The method can help learners improve language fluency and language accuracy in writing, so as to avoid grammatical errors in some sentence structures. But the study found that after the teaching practice of traditional teaching method of lexical chunks, learners have no problem in lexical chunks according to the grammatical structure, but still lack of strong sensitivity in the pragmatic functions of lexical chunks in a certain context. Learners find it difficult to distinguish language chunks of written and spoken English and still lack of sensitivity of lexical chunks which are grammatically correct but are not in conformity with the native language habits.

\section{The NeW TeAChING Mode Of LEXICAL CHUNKS BASED ON LANGUAGE CONSCIOUSNESS}

In view of the above research, the author thinks that language consciousness is kind of implicit language ability, so the process of building lexical chunks among Chinese students should be generated from the internal construction ability. This strengthens the internalization process and explicit result of language form and structure sensitivity. In this process, the learners transform the "hidden" language knowledge into the "dominant" language output and reduce the interference of mother tongue, so as to achieve the purpose of language awareness and lay a solid foundation for the improvement of language learners' autonomous learning ability. Here, the author analyzes three major principles need paying attention to in order to strengthen the lexical chunk teaching method and cultivate the language consciousness.
TABLE I. MAJOR PRINCIPLES OF LEXICAL CHUNK TEACHING METHOD

\begin{tabular}{|c|l|}
\hline Principles & \multicolumn{1}{c|}{ Performance } \\
\hline 1 & $\begin{array}{l}\text { Learners' ability of recognizing the function of lexical chunks in } \\
\text { various genres, especially to strengthen learners' sensitivity of } \\
\text { the use of lexical chunks corresponding to the various kinds of } \\
\text { literary style. }\end{array}$ \\
\hline 2 & $\begin{array}{l}\text { Learners' ability to use critical consciousness to understand the } \\
\text { native speakers' habit for the use of lexical chunks }\end{array}$ \\
\hline 3 & $\begin{array}{l}\text { Language learners in the process of reproducing lexical chunks } \\
\text { or groups can implement the internalization, construction and } \\
\text { generalization of lexical chunks, thereby effectively keeping } \\
\text { close to native language output ability for a long time }\end{array}$ \\
\hline
\end{tabular}

This is the new connotation that lexical language teaching method produces when instructing college English writing driven by language consciousness theory. The author will make a combination of language consciousness theory and lexical chunk teaching method and tries to design a new mode of teaching lexical chunks in the college English writing class[3].

Step 1: Conscious cognition of lexical chunks. Before class: in view of a topic, each of the students can look for all kinds of original corpus individually or in groups in order to observe and find language chunks and then classify lexical chunks into different categories. In class: the teacher organizes classroom teaching effectively and requires students to categorize lexical chunks according to different style, language context and pragmatic functions on the basis of the features of language, especially to separate written and spoken language chunks. In the process of classification, the students, under the guidance of teachers, can understand which kind of lexical chunk conforms to the native language habit. After class, students recite and remember the good language chunks in the context conforming to different cases.

Step 2: Conscious study of lexical chunks. Before class: organize students to collect lexical chunks provided with the same pragmatic functions. In class: unfold language chunks, explore lexical chunks' generativity and then summarize and share language chunks and phrases. In the context of different styles, repeatedly practice using lexical chunks and phrases. After class, students according to different context generate more phrases using inductive language or group, and learn to memorize them.

Step 3: conscious use of lexical chunks. Before class, require students to collect compositions with the same subject in different groups and then induce language chunks. In class: students through self-evaluation and mutual assessment refer to the written form in the target language and discuss over lexical chunks in terms of grammatical correctness, language accuracy, language fluency and content integrity to judge whether the chunks are in line with the contexts[4]. Teachers and students, through mutual discussion, analyze and summarize the existing errors of lexical chunks in the process of using in the structure and function and finally correct them.

After class: the students remember the characteristics of language chunks, repeatedly practice lexical chunk in composition writing and expand self-assessment and mutual recognition combined with a variety of literary style offered by teachers. It strengthens students' sensitivity of using lexical chunks with a variety of forms and the use of written language chunks is closer to the expressive habit of native language. 
Courses require students to compile the lexical chunks inside and outside the classroom and master them, and continue to summarize lexical chunks according to its structure and function in autonomous learning process and finally expand the number of lexical chunks. New mode of English writing teaching pays more attention to strengthening learners' consciousness of lexical chunks of different styles, through self-evaluation and mutual recognition, practicing using lexical chunks before and after class to strengthen the consciousness of written language and internalization of generating capacity, so as to improve the overall sensitivity of language in turn by increasing sensitivity of lexical chunks and provide students with English language output ability close to the native language.

\section{ENGLISH WRITING TEACHING STRATEGY ANALYSIS UNDER THE THEORY OF LEXICAL CHUNKS}

In light of the status quo of current college English writing teaching and the important role of lexical chunks in English writing, how to infiltrate the consciousness of lexical chunks to concrete writing teaching process, take lexical chunks as the core and promote college English writing teaching has become a top priority. English writing teaching strategies based on the theory of lexical chunks should mainly involves the following links:

\section{A. Input of lexical chunks}

First of all, cultivate the students' consciousness of lexical chunks. Language chunk has not been approved in the past years and the advantages of lexical chunks were seriously neglected, therefore, in the current English writing teaching process, teachers must change students' simple understanding of words and consciously guide students to give full play to the role of lexical chunks in English writing, so that the students gradually learn the importance of lexical chunks in language learning, abandon the inertial thinking in the past and get into the habit of language learning by mastery of lexical chunks[5].

Secondly, improve students' language recognition ability. Second language prefabricated chunk recognition ability cannot be generated automatically. Even though the second language learners have reached a higher level of language, their prefabricated chunk recognition ability must be consciously developed and achieved through systematic training. In the teaching, teacher through the demonstration of lexical chunks can help students establish the concept of lexical chunks, help students establish a rational understanding of lexical chunks and learn about the definition, classification, characteristics and functions of lexical chunks. At the same time, because lexical chunks are fixed or semi-fixed language units that non-native speakers are unable to independently create, the input of a large number of real target language in language acquisition plays an important role in the process of language learning, therefore, teachers should inspire students to learn lexical chunks from textbooks, extracurricular reading materials and authentic language materials and identify, collect and reserve lexical chunks gradually. In this way, students can pay attention to lexical chunks consciously, contact and memorize a lot of language chunks and phrases and summarize the language structures from the fixed or semi-fixed prefabricated materials with language significance and language functions, and finally experience the role of lexical chunks in writing. This through pay attention to the identification, analysis, memory process is active language knowledge construction process, not only cultivate the students recognize the ability of language chunks, enhance the students' consciousness of lexical chunks, but also paved the way for the implementation of the teaching of lexical chunks[6].

\section{B. Output of lexical chunks}

At the primary stage of lexical chunks acquisition, in order to encourage students to consciously use and master what language chunks they have learned, teachers should guide students to imitate and use new language chunks. Students' repeated imitation and reinforcement in language learning can effectively promote language acquisition. If students can do it in the process of writing output, their writing level will be improved in virtually.

\section{Autonomous learning}

There are a large number of lexical chunks in English, so it is not realistic to teach language knowledge within the limited class time. The key is to cultivate students' autonomous learning ability and pay attention to the principal role of students in the learning process of lexical chunks, thus, students are required to accumulate a large number of language chunks, consciously cultivate their language using ability and reduce the dependence on teachers. At the same time, teachers need to strengthen the language learning strategy training which can achieve twice the result with half the effort.

\section{CONCLUSION}

Prefabricated chunks are highlighted an important position in college English writing teaching. Firstly, the English writing level of college students is generally low. In the eyes of many students, writing is considered to be the most difficult. In the usual classes, few teachers set aside time for writing training. Students usually do not develop the habit of writing essays or diaries. Writing assignments normally appear in the unit test or midterm and final exams. Secondly, to introduce teaching strategies of prefabricated chunks into college writing teaching has a positive significance in college English writing teaching. Students can timely elect the useful chunks from their memorization in writing, which helps them organize language in such a limited period of time and helps to avoid grammatical errors, misnomer and vague expression committed by the students. Finally, although prefabricated chunks have a positive effect raising the level of students' writing, this effect also varies from different students. Prefabricated chunks have a positive impact on the whole, but have little effect on the individual student. When comes to prefabricated chunks' incidence in improving student writing levels, some students will get a lot of improvement in the level, from the previous failure in writing to today's excellence in writing . However, minority of the students said that their levels of writing are improved a little and the effect is not very obvious , which may be because this small part of the student are not very acceptable to the new teaching method but prefer traditional English 
teaching method. The author thinks that it is inevitable that the existence of such differences occurred in experiment.

\section{REFERENCES}

[1] Alison Wray. A formulaic language and the lexicon, Cambridge: Cambridge University Press.2002

[2] Becker, J.1975. The phrasal lexicon. , Cambridge Mass: Bolt \& Newman..Becker J.1975. The phrasal lexicon [M]. Cambridge, Mass: Bolt, Be-ranek, and Newman.
[3] Lewis, M. 1993. The Lexical Approach: the state of ELT and a way forward. [M]. Hove: Language Teaching Publications

[4] Granger.S.Prefabricated Patterns in Advanced EFL Writings Collocations and Formula. [A] In Cowei.A.P. Phraseology Theory, Analysis and Application.[C] Oxford:Clarendon Press.1998

[5] Moon. R. Frequences and Forms of Phrasal Lexemes in English[A] In Cowei. A.P. Phraseology Theory, Analysis and Application.[C] Oxford: Clarendon Press.1998

[6] Pawley, A., \& Syder, F. (1983). Two puzzles for linguistic theory: Native-like selection and native-like fluency. In J. Richards \& R. Schmidt (Eds.), Language and communication (pp. 191-226). London: Longman. 